\title{
Faktor-faktor yang Mempengaruhi Penyerapan Hukum Islam dalam Perundang-Undangan Pada Era Orde Baru (1965 s/d 1998)
}

\author{
Jurna Petri Roszi \\ STAI-YASTIS Padang \\ Jurnapetri_roszi@yahoo.co.id
}

\begin{abstract}
The Soeharto government became an interesting theme for nearly every research because of uniqueness of the rule known as the authoritarian nature. However, the uniqueness is only studied until the result of the authoritarian who has raised the anxiety of almost all the people and eventually led to the cessation of Soeharto as head of the State Indonesia. Judging from the perspective of law, the political transition of the period not only political influence, but also influenced the formation of law. This research will discuss about factors influencing absorption of Islamic Law into legislation. In the Order Baru era efforts to ground Islamic law into legislation experienced a variety of responses, both from among Muslims and non-Muslims. Factors affecting the absorption of Islamic law in Indonesia can not be separated from the perennial struggles and tensions in positioning religious relations (shari'a) and the state, between the secularization project and the Islamization of the state and society. This tension occurs in two different important settings. First, the level of scholastic or theoretical-idealistic. Second, the realistic-politic or ideological-empirical level. The debate within the ideological framework has implications for the legal sphere debate. The same complexity is also encountered in internal Muslims because the meaning of sharia itself has its own problems. Where the mazhab of thought and Islamic legal system is not single. The findings of this research is the development of Islamic law in the Order Baru era seen from the legal products that serve as case studies in this study such as UU no. 1 year 1974 about Marriage born at the time of Indonesian political configuration is in otteriter political configuration, but the character of Islamic law product that produced is responsive. Likewise law products UU no. 7 of 1989 on Religious Courts, from the perspective of the formation of a law of responsive character because it is accommodative to Religious Courts institution which is an important part in institutional Islamic law in Indonesia, although UU no. 7 Year 1989 was born when the authoritarian political configuration and in terms of implementation of legal material is conservative. This is seen from the low attention of the political elite to realize the UUPA and even the existence of the institution has existed long before the formal law. In addition, the birth of UUPA is late compared to other judicial laws. Furthermore, the same thing happened to the Compilation of Islamic Law, the Order Baru government's configuration is still considered undemocratic. But in terms of content fully contains the provisions raised from the books of Islamic jurisprudence fiqh containing aspects of marriage, inheritance and perwakafan law.
\end{abstract}

Keywords: Islamic Law, Order Baru, Legislation

FOKUS : Jurnal Kajian Keislaman dan Kemasyarakatan vol. 2, no. 2, 2017

P3M Sekolah Tinggi Agama Islam Negeri (STAIN) Curup - Bengkulu

Available online: http://journal.staincurup.ac.id/index.php/JF

p-ISSN 2548-334X, e-ISSN 2548-3358 


\begin{abstract}
Abstak
Pemerintahan Soeharto menjadi suatu tema yang menarik bagi hampir setiap penelitan karena keunikan pemerintahannya yang bersifat otoriter. Namun keunikan tersebut hanya diteliti hingga akibat dari otoriternya yang menimbulkan keresahan hampir di kalangan masyarakat dan akhirnya berujung dengan pemberhentian Soeharto sebagai kepala Negara Indonesia. Jika dilihat dari kacamata hukum, transisi politik pada masa itu tidak hanya berpengaruh pada politik, tapi juga berpengaruh pada pembentukan hukum. Penelitian ini akan membahas menganai faktor-faktor yang mempengaruhi penyerapan Hukum Islam ke dalam perundang-undangan. Pada masa Orde Baru usaha untuk membumikan hukum Islam ke dalam perundang-undangan mengalami tanggapan yang beragam, baik dari kalangan umat Islam sendiri maupun dari kalangan non Muslim. Faktor yang mempengaruhi penyerapan hukum Islam di Indonesia tidak bisa terlepas dari pergumulan dan ketegangan abadi dalam memosisikan relasi agama (syariat Islam) dan negara, antara proyek sekularisasi dan islamisasi negara dan masyarakat. Ketegangan ini terjadi dalam dua tataran penting yang berbeda. Pertama, tataran scholastik atau bersifat teoritik-idealistik. Kedua, tataran realistic-politic atau ideologi-empirik. Perdebatan dalam rangka ideologis tersebut berimplikasi pada perdebatan ranah hukum. Kerumitan yang sama juga ditemui dalam intern umat Islam karena pemaknaan terhadap syariah itu sendiri memiliki problema tersendiri pula. Di mana mazhab pemikiran dan sistem hukum Islam tidak tunggal. Adapun hasil temuan dari penelitian ini yaitu perkembangan hukum Islam pada masa Orde Baru dilihat dari produk hukum yang dijadikan sebagai studi kasus dalam kajian ini misalnya UndangUndang No. 1 tahun 1974 tentang Perkawinan yang lahir pada saat konfigurasi politik Indonesia sedang dalam konfigurasi politik oteriter, tapi karakter produk hukum Islam yang dihasilkannya bersifat responsif. Begitu juga produk hukum UU No. 7 tahun 1989 tentang Peradilan Agama, dari perspektif pembentukan hukum berkarakter responsif karena akomodatif terhadap lembaga Pengadilan Agama yang menjadi bagian penting dalam kelembagaan hukum Islam di Indonesia, walaupun Undang-Undang No. 7 Tahun 1989 ini lahir saat konfigurasi politik otoriter dan dari segi implementasi materi hukumnya bersifat konservatif. Hal ini dilihat dari rendahnya perhatian elit politk untuk merealisasikan UUPA dan malah keberadaan lembaganya sudah ada jauh sebelum hukum formilnya. Di samping itu, kelahiran UUPA terlambat dibandingkan dengan undang-undang peradilan lainnya. Selanjutnya, hal yang sama juga terjadi pada Kompilasi Hukum Islam, konfigurasi pemerintahan Orde Baru masih dinilai tidak demokratis. Namun dari segi isi sepenuhnya berisi ketentuan-ketentuan yang diangkat dari kitab-kitab figh rujukan umat islam yang memuat aspek-aspek hukum perkawinan, kewarisan dan perwakafan.
\end{abstract}

Kata kunci: Hukum Islam, Orde Baru, Perundang-undangan

\title{
PENDAHULUAN
}

Orde Baru dimulai sejak keluarnya surat perintah sebelas Maret 1966. Pada awalnya memberikan harapan baru bagi dinamika perkembangan Islam khususnya hukum Islam di Indonesia. Harapan ini muncul setidaknya disebabkan oleh kontribusi yang cukup besar diberikan oleh umat Islam dalam menumbangkan Orde Lama. Hal ini bisa 
Jurna: Faktor-faktor yang Mempengaruhi Penyerapan Hukum Islam... | 153 dilihat dari dibebaskannya sejumlah tokoh politik Islam (tertama tokoh Masyumi) dari tahanan Soekarno tahun 1966, sehingga menimbulkan kerinduan dan optimisme terhadap partai politik Islam. Pada tahun 1960 mantan ketua Masyumi Prawoto Mangkusasmito sangat aktif ingin mewujudkan rehabilitasi Masyumi sebagai Partai politik. Akan tetapi, usaha tersebut mendapat tantangan yang sangat keras dari pelbagai pihak, terutama dari Angkatan Darat, kalangan Kristen/Katolik, dan para tokoh Partai Nasional Indonesia. Bahkan ketika tuntutan umat Islam semakin menguat, pemerintah justru mengambil kebijakan untuk memperkecil ruang gerak politik mereka. Militer kemudian semakin tegas mengklaim kedudukannya sebagai pembela utama UUD 1945 dan Pancasila. Militer juga tidak segan-segan melawan kekuatan yang dipandang hendak menggantikan UUD 1945 dan Pancasila. Keberatan militer terhadap rehabilitasi Masyumi dilatarbelakangi traumanya akan simpati Masyumi kepada pemberontakan Pemerintahan Revolusioner Republik Indonesia (PRRI) dan banyak tokoh-tokohnya yang terlibat dalam peristiwa tersebut. Secara formal alasan penolakan terhadap rehabilitasi Masyumi adalah persoalan hukum dan psikologis. Padahal yang sebenarnya akibat dari kekhawatiran dihadirkannya kembali Masyumi, kekuatan politik Islam akan dengan mudah dimobilisasikan sehingga menjadi satu kekuatan politik yang sangat besar.

Keberatan pemerintah untuk merehabilitasi Masyumi mendorong sebagian umat Islam untuk mencari jalan lain untuk menghidupkan partai Islam. Pada tanggal 7 April 1967 Badan Koordinasi Amal Muslim (BKAM) membentuk Kelompok Tujuh untuk merancang pembentukan partai baru menggantikan Masyumi. Pada tanggal 5 Februari 1968 pemerintah menyetujui berdirinya Partai Muslimin Indonesia (PARMUSI) sebagai gabungan partai Islam, sebagaimana diusulkan BKAM. Namun pemerintah mensyaratkan Parmusi bukanlah Masyumi (mantan pemimpin Masyumi tidak boleh memimpin Parmusi).

Persetujuan berdirinya Parmusi belum menjamin terakomodasinya aspirasi politik Islam. Buktinya pemerintah selalu mencampuri Parmusi dalam hal kepemimpinan. Ketika Partai Muslimin Indonesia (PARMUSI) untuk pertama kalinya mengadakan Muktamar pada tanggal 4-7 November 1968 di Malang Jawa Timur. Peserta muktamar sepakat memilih Mr. Muhammad Roem sebagai Ketua Umum Partai Muslimin Indonesia. Menurut Muktamirin, walaupun Roem salah seorang anggota bekas pimpinan Partai Masyumi, ia bersih dari dosa politik Masyumi (yaitu simpati kepada pemberontakan PRRI), bahkan tidak jarang 
Muhammad Roem berseberangan dengan tokoh karismatik Masyumi M. Natsir.

Dengan latar belakang demikian, Parmusi optimis bahwa pemerintah tidak akan keberatan dengan naiknya Roem sebagai Ketua Umum Parmusi. Akan tetapi pemerintah dan Angkatan Darat berkeberatan terhadap Muhammad Roem karena beliau merupakan tokoh Masyumi yang masih sangat berpengaruh. Hal ini diperlihatkan dalam kebijakan Presiden yang meminta Jendral Alamsyah Ratuprawiranegara sebagai Sekretaris Negara mengirim telegram ke Malang untuk menginformasikan bahwa pemerintah tidak dapat menerima Muhammad Roem. Sebagai jalan keluar yang terbaik pada waktu itu kongres memilih duet antara Djarnawi Hadikusumo sebagai Ketua dan Lukman Harun sebagai Sekretaris Jendral Partai Muslimin Indonesia. Keduanya berasal dari Muhammadiyah sebagai komponen terbesar dari partai tersebut. Namun kepemimpinan Djarnawi Hadikusumo dan Lukman Harun tidak dapat bertahan dengan baik. Pihak pemerintah tampaknya kesulitan untuk menerima kedua tokoh tersebut karena dianggap keras sekali dan dipandang tidak akomodatif. Atas rekayasa dari pihak opsus yang dipimpin oleh Ali Murtopo, kepemimpinan Partai Muslimin Indonesia diambil alih oleh Jaelani Naro dan Imran Kadir. Terpilihnya Jaelani Naro dan Imran Kadir sebagai ketua dan wakil ketua, menimbulkan konflik internal dalam tubuh partai. Akibatnya, pemerintah menunjuk MHS. Mintareja salah seorang anggota kabinet Soeharto sebagai Ketua Partai Muslimin menggantikan Djarnawi Hadikusumo (20 November 1970). Sejak saat itu ketegangan antara pemerintah dan Islam mulai muncul di permukaan karena para aktivis dan pemimpin partai agama mulai menunjukkan oposisi yang jelas.

Cendekiawan Muslim yang muncul pada 1970-an telah menerima dengan mantap ide Negara Nasional berdasarkan Pancasila, baik secara teoritis maupun praktek. Menjelang diadakannya Pemilihan Umum (pemilu) pertama masa pemerintahan Orde Baru, Nurcholis Majid melontarkan gagasan yang kemudian memicu kontroversi di kalangan umat Islam. Sekalipun gagasan itu tidak secara langsung ditawarkan dalam kaitannya dengan pelaksanaan pemilu, namun karena waktu itu dekat dengan pelaksanaan Pemilu, menjadikan lontaran Nurcholish Majid sangat penting dari dilihat sudut politik. Dalam ceramah di Taman Ismail Marzuki (TIM), Jakarta, pada 21 Oktober 1972, Nurcholis menggarisbawahi perlunya pembaharuan pemikiran dalam Islam. Anjurannya terpusat pada dua gagasan utama, yaitu: (1) Gagasan sekulerisasi; dan (2) Penolakan terhadap dijadikannya Islam sebagai 
Jurna: Faktor-faktor yang Mempengaruhi Penyerapan Hukum Islam... | 155 ideologi politik dengan pernyataannya yang terkenal Islam "yes", partai Islam "no".

Ketika menghadapi pemilihan umum tahun 1971, konflik antara kebijakan partai yang membawakan aspirasi Islam dengan pihak pemerintah berkelanjutan. Konflik ini disebabkan oleh: Pertama, berkaitan dengan kebijakan Menteri Dalam Negeri No.12 yang dipandang sebagai suatu usaha untuk melakukan pengebirian terhadap partai-partai politik di Indonesia. Kedua, Lembaga Pemilihan Umum yang diketuai oleh Mendagri memangkas dalam jumlah yang sangat besar calon-calon yang diajukan oleh Partai Muslimin Indonesia yang sangat berpengaruh. Sebab kalau mereka dibiarkan aktif dalam proses penyelenggaraan Pemilu tentu saja akan sangat melemahkan partai pemerintah, Golkar. ${ }^{1}$

Belum sembuh luka akibat perolehan suara yang tidak memuaskan pada Pemilu 1971, umat Islam dihadapkan kepada program pengembangan sistem politik hegemonis. Pada bulan Januari 1973 pemerintah memutuskan untuk melakukan restrukturalisasi sistem kepartaian. Dalam struktur politik yang baru ini, seluruh partai kecuali Golkar, harus bergabung ke dalam dua partai politik. Keempat partai Islam NU, Parmusi, PSII, dan Perti digabung ke dalam Partai Persatuan Pembangunan (PPP), sedangkan lima partai lainnya yang berlatar belakang nasionalis (PNI, IPKI, dan Murba), Kristen Protestan (Parkindo) dan Katolik (Parkat), digabung ke dalam Partai Demokrasi Indonesia (PDI). Sebagai akibat dari penggabungan yang dipaksakan, terjadilah konflik internal di dalam kedua partai baru, PPP dan PDI. Walaupun PPP lebih diuntungkan oleh karakter keislaman dan karena elite partai adalah juga elite organisasi keagamaan, hal itu tidak menjamin kesatuan yang utuh. Konflik di tubuh PDI tampaknya lebih kompleks jika dibandingkan dengan konflik di PPP. Selain itu, meskipun pemerintah telah merestrukturisasi sistem kepartaian, intervensinya dalam dua partai tidak menyusut. Setiap ada konflik internal partai, pemerintah turut campur dengan alasan sebagai pembina politik.

Ketika pelemahan politik Islam mencapai titik puncaknya dengan memberlakukan asas tunggal mendorong sebagian dari mereka untuk merumuskan kembali makna dan strategi politik Islam lebih jauh. Dengan dipersempitnya ruang gerak bagi politik Islam dalam bentuk formal, dijadikan peluang untuk memasuki wilayah politik melalui jalan lain yang dipandang masih sangat terbuka. Mereka menganggap perlu

\footnotetext{
${ }^{1}$ Affan Ghafar, Islam dan Politik Dalam Era Orde Baru: Mencari Bentuk Artikulasi yang Tepat. (Jakarta: Ulmul Qur'an.1993), hlm.19-20
} 
mengakomodasi gagasan pemerintah untuk mengikis kecurigaan antara Islam dan negara.

Realitas politik Islam yang dipandang gagal memotivasi umat Islam, terutama kalangan cendekiawan mudanya yakni mencari rumusan baru politik agar dapat berperan dalam negara. Salah satunya adalah melakukan reorientasi terhadap makna politik Islam yang selama itu dielaborasi dalam corak legalistis dan formalistis. Orientasi politik baru tersebut lebih mengarah kepada politik substantif dan integratif. Atau dengan kata lain, pendekatan baru mengutamakan kandungan nilai islam sebagai sumber inspirasi bagi kegiatan politis serta sikap saling menerima dan menyesuaikan antara umat islam dan negara.

Tarik ulur antara kepentingan rezim Orde baru dengan politik hukum Islam yang dimainkan oleh para cendekiawan muslim di Indonesia, menciptakan hubungan antara konfigurasi politik dengan produk hukum yang dihasilkan. Konfiguarasi politik sendiri diartikan sebagai susunan atau konstelasi kekuatan politik yang secara secara dikotomis dibagi atas dua konsep yang bertentangan secara diametral, yakni konfigurasi politik demokratis dan konfigursi politik otoriter.

Konfigurasi politik yang ada pada suatu negara akan melahirkan karakter produk hukum tertentu. Pada negara dengan konfigurasi politik demokratis akan menghasilkan karakter hukum yang responsi/populistik, sementara itu untuk negara dengan konfigurasi politik otoriter akan menghasilkan produk hukum dengan karakter ortodok/konservatif/elitis.

Dari latar belakang kajian penelitian ini menitikberatkan pada apa yang melatar belakangi terbentuknya hukum Islam di Indonesia dan faktorfaktor yang mempengaruhi penyerapan hukum islam dalam perundangundangan pada era orde baru (1965 s/d 1998)? Adapun manfaat dari menganalis data tersebut diharapkan secara teoritis, praktis dan akademis. Secara praktis penelitian ini diharapkan memberikan gambaran tentang proses pembentukan, perubahan dan pemberlakuan hukum Islam dalam bentuk perundang-undangan, terutama bagi para praktisi hukum secara umum, dan secara khusus bagi praktisi hukum di lingkungan Peradilan Agama. Secara teoritis, dapat dilakukan pengembangan ilmu-ilmu keislaman, terutama tentang teori pemberlakuan hukum Islam dan teori perubahan hukum di Indonesia; dan secara akademis, memperkuat lahirnya teori dan sistem pembentukan hukum Islam dalam tata hukum di Indonesia melalui berbagai kajian dan penelitian yang terstruktur.

Penelitian ini menggunkan metode sejarah. Metode sejarah menurut Louis Gottschalk adalah proses pengujian secara kritis terhadap peninggalan masa lampau. Metode penelitian sejarah terdiri atas empat 
Jurna: Faktor-faktor yang Mempengaruhi Penyerapan Hukum Islam... | 157 tahap yaitu heuristik, kritik sumber, interpretasi dan histografi. Setelah data terkumpul, kemudian ditarik dengan membandingkan atara data yang satu dengan yang lainnya dengan mempertimbangkan aspek validitas data. Sumber data yang telah disaring kemudian ditafsirkan melalui interpretasi terhadap fakta-fakta sejarah. Fakta ini kemudian disusun menjadi sebuah konstruksi suatu peristiwa yang utuh. Pada tahap ini teori dan metode pendekatan berfungsi sebagai alat untuk mengalisis sekaligus menjelaskan peristiwa. Langkah terakhir adalah menggunakan historiografi sehingga diperoleh penulisan sejarah yang deskriptif analitif. Faktor-Faktor yang Mempengaruhi Penyerapan Hukum Islam dalam Perundang-Undangan di Masa Ode Baru

Indonesia moderen jika ditinjau dari perspektif religio-politis, syariat Islam dan negara adalah dua entitas yang sepanjang sejarah Indonesia senantiasa terlibat pergumulan dan ketegangan abadi dalam memosisikan relasi agama (syariat Islam) dan negara, antara proyek sekularisasi dan Islamisasi negara dan masyarakat. Ketegangan ini terjadi dalam dua tataran penting yang berbeda. Pertama, tataran scholastik atau bersifat teoritik-idealistik.2 Kedua, tataran realistic-politic atau ideologiempirik. Perdebatan dalam rangka ideologis tersebut berimplikasi pada perdebatan ranah hukum. Konflik dan pergumulan dalam ranah ini terjadi sebagai konsekuensi dari: pertama, dilihat dari segi pluralitas jenis penduduknya, masyarakat Indonesia mempunyai sistem hukum yang berlaku sejak zaman primitif dari kebiasaan atau adat istiadat sampai dengan ketentuan yang diyakini bersama untuk dipatuhi. Kebiasaan atau adat istiadat ini disebut hukum adat, hukum kebiasaan (customary law) atau hukum yang hidup di tengah-tengah masyarakat (the living law). Kedua, dari segi agama terdapat nilai-nilai agama yang diyakini bersama dijadikan sebagai sistem kehidupan yang dianggap sebagai hukum yang bersumber pada agama yang diyakini sebagian besar masyarakat. Ketiga, sebagian negara yang pernah dijajah selama 350 tahun, maka kolonial Belanda jelas membawa sistem hukum Belanda ke Indonesia dan bahkan memaksakan hukumnya kepada masyarakat jajahannya.3 Ketiga faktor ini melahirkan tiga sistem atau mazhab hukum di Indonesia yaitu hukum adat, hukum islam dan hukum Barat (sipil).4 Oleh sebab itulah sangat

${ }^{2}$ Deliar Noer, Gerakan Modern Islam di Indonesia 1990-1942, cet. VIII, (Jakarta: LP3ES, 1996), hlm. 296-297

${ }^{3}$ A. Qodry Azizi, Hukum Nasional Elektisisme Hukum Islam \& Hukum Umum, (Jakarta: Teraju, 2004), hlm. 138-139

${ }^{4}$ Subekti, Law in Indonesia, (Jakarta: Yayasan Proklamasi Center for Starategic and International Studies, 1982), hlm. 6 
beralasan penilaian Daniel S. Lev yang menyatakan bahwa sistem hukum di Indonesia merupakan satu dari sekian banyak sistem hukum yang lebih rumit di dunia.5

Selain problem politis dalam transformasi nilai-nilai Islam ke dalam perundang-undangan negara, kerumitan yang sama juga ditemui dalam intern umat Islam karena pemaknaan terhadap syariah itu sendiri memiliki problema tersendiri pula. Di mana mazhab pemikiran dan sistem hukum Islam tidak tunggal. Varian dan corak pemikiran dalam menyikapi hubungan syariah dan negara melahirkan tiga persimpangan jalan.6 Pertama, satu jalan menuju pemberlakuan hukum Islam berasal dari kelompok yang menghendaki hukum Islam dapat berlaku di Indonesia untuk mengatur pemeluknya. Kedua, satu jalan dari kelompok yang menginginkan adanya kesatuan dan keseragaaman hukum. Agama hanya sebagai bahan baku dalam pembentukan hukum nasional.7 Paradigma berpikir kelompok ini adalah menjaga hubungan antara syariat dan negara. Pada kondisi tertentu dilakukan formalisasi hukum Islam dalam perundang-undangan negara, pada saat yang lain Islam sebagai sumber etika moral. Perspektif ini disebut moderat-konstitusional. Ketiga, simpang jalan lainnya adalah kelompok yang tidak menginginkan berlakunya hukum Islam secara terlembaga dan bahkan ada kecenderungan menyingkirkan hukum Islam.8 Kubu pendukung paham ini diwakili sebagian besar non muslim dan sebagian kecil umat islam beraliran nasionalis sekuler. Perspektif ini disebut liberal-sekularistik.

Menurut J.N.D Anderson tiga sikap itu menjadi ciri umum dunia Islam dalam penerapan syariah. Tiga sikap dunia Islam ini sejalan dengan sikap masyarakat Indonesia dalam menyikapi syariah dalam negara. Sikap ini jelas tidak terhindar dari polemik dan kepentingan politik dalam menentukan posisi syariah dalam negara. Bahkan jika dilihat dari teori sosial khususnya critical theory, polemik itu tidak bisa dilepaskan dari kepentingan politik penguasa, masyarakat dan elit politik. Oleh karena

\footnotetext{
${ }^{5}$ Daniel S. Lev, Peradilan Agama Islam di Indonesia Suatu Studi Tentang Landasan Politik Lembaga-lembaga Hukum. Alih bahasa oleh Zaini Ahmad Noehlm, (Jakarta: Intermasa, 1986), hlm. 24

${ }^{6}$ Satria Effendi M. Zein, Ijtihad Sepanjang Sejarah Hukum Islam: Memposisikan KHLM. Ali Yafie, dalam Jamal D. Rahman (ed), Wacana Baru Fiqh Sosial 70 Tahun KHLM. Ali Yafie, (Bandung: Mizan, 1997), hlm. 153-156

${ }^{7}$ Munawir Sjadzali, Islam dan Tata Negara, Ajaran, Sejarah dan Pemikiran, (Jakarta: UI Press, 1993), hlm. 1

8 Satria Effendi M. Zein, Munawir Sjadzali dan Reaktualisasi Hukum Islam di Indonesia, dalam Muhammad Wahyu Nafis, (ed). Kontektualisasi Ajaran Islam 70 Tahun Prof. Dr. H. Munawir Sjadzali. MA, (Jakarta: Paramadina, 1995), hlm. 288-289
} 
Jurna: Faktor-faktor yang Mempengaruhi Penyerapan Hukum Islam... | 159 itu, sebenarnya di balik pemikiran apapun, pada hakekatnya implisit atau eksplisit mempunyai kandungan dan implikasi politik.9 Perbedaan paradigma pemikiran itu terlihat jelas ketika terjadi interaksi antara pusatpusat kekuasaan (power points) baik di tingkat inpra-struktur maupun supra-struktur di tengah-tengah masyarakat seperti pemerintah, ABRI, ormas keagamaan/lembaga swadaya masyarakat, masyarakat muslim dan non muslim serta media masa dalam proses legislasi hukum Islam di Indonesia. Hal itu dapat dilihat dengan jelas pada waktu proses pembentukan UU No. 1 tahun 19974 tentang Perkawinan dan UU No. 7 tahun 1989 tentang Peradilan Agama, merupakan contoh bagaimana polapola interaksi dan dinamika konflik dan akomodasi yang muncul pada masa Orde Baru dan mengundang perdebatan yang cukup sengit. Perdebatan-perdebatan itu bahkan dikaitkan dengan persoalan hak asasi manusia, isu negara Islam dan Piagam Jakarta.

Lebih lanjut, penyerapan hukum Islam tidak dapat dipisahkan dari konfigurasi kekuatan dan kepentingan yang ada dalam masyarakat. Setidaknya ada tiga faktor penting: Pertama, aspek situasi konfigurasi politik domokrasi dan otoriter. Dalam konteks hukum Islam, konfigurasi politik tidak secara signifikan ikut mempengaruhi substansi produk hukum Islam yang diundangkan, tetapi bila dilihat dari segi proses politik dapat mengikuti konfigurasi politik. Dari aspek karakter hukum Islam ada beberapa kemungkinan produk yang lahir. Pertama, responsif yang berarti secara politis produk hukum ini lahir secara demokratis dan secara yuridis sejalan dengan substansi hukum Islam yang dianut umat Islam Indonesia dan dalam mekanisme pengundangannnya bersifat pluralistik/kompotitif. Kedua, responsif-yuridis, artinya secara politik produk hukum Islam yang lahir tidak dalam konfigurasi politik demokratis atau bahkan berada dalam konfigurasi politik otoriter, tetapi dipandang dari substansial memenuhi syarat minimal dari substansi hukum Islam atau minimal tidak bertentangan dengan hukum islam. Ketiga, konservatif, yakni produk hukum Islam yang jelas-jelas bertentangan dengan substansi hukum dan mekanisme lahirnya cenderung sentralistik.

Kedua, politik hukum Islam di Indonesia bila dilihat dari faktor isi produk undang-undang mengenai hukum Islam yang lahir dari model negara Indonesia dapat bersifat responsif dan konservatif. Hal itu dapat dibuktikan pada waktu perumusan UU No. 1 tahun 1974 tentang Perkawinan yang lahir pada saat konfigurasi politik Indonesia sedang

\footnotetext{
${ }^{9}$ Fahry Ali dan Bahtiar Effendy, Merambah Jalan Baru Islam Rekonstruksi Pemikiran Islam Masa Orde Baru, (Bandung: Mizan, 1986), hlm. 9
} 
dalam konfigurasi politik oteriter, tapi karakter produk hukum Islam yang dihasilkannya bersifat responsif. Dari segi isi UU ini disebut responsif karena seluruh pasal- pasal yang termaktub dalam UU No. 1 tahun 19974 tentang Perkawinan telah sejalan dengan hukum Islam atau sekurangkurangnya tidak bertentangan dengan hukum Islam. Begitu juga produk hukum UU No. 7 tahun 1989 tentang Peradilan Agama, dari perspektif pembentukan hukum berkarakter responsif karena akomodatif terhadap lembaga Pengadilan Agama yang menjadi bagian penting dalam kelembagaan hukum Islam di Indonesia. Walaupun Undang-Undang No. 7 Tahun 1989 ini lahir saat konfigurasi politik otoriter. Hal yang sama juga terjadi pada Kompilasi Hukum Islam, konfigurasi pemerintahan Orde Baru masih dinilai tidak demokratis. Namun dari segi isi sepenuhnya berisi ketentuan-ketentuan yang diangkat dari kitab-kitab fiqh rujukan umat Islam yang memuat aspek-aspek hukum perkawinan, kewarisan dan perwakafan.

Berdasarkan bukti-bukti karakter produk hukum Islam pada masa Orde Baru dapat dinilai bahwa hubungan Islam dan negara pada pemerintahan Soeharto terdapat pola atau periode antagonistik (19671982), resiprokal kritis (1982-1985) dan akomadatif (1984-1994). Penilaian anatagonistik pada masa awal-awal Orde Baru hanya tepat untuk menggambarkan hubungan Islam politik dan negara Orde Baru karena bersimpang jalannya kepentingan antara kepentingan Islam politik dengan pemerintahan Orde Baru yang berorientasi pada penguatan modernisasi pembangunan, kebangsaan dan keIndonesiaan, sementara Islam politik berorientasi pada formalistik agama untuk membuka ruang yang seluas-luasnya bagi Islam politik termasuk ideologi negara. Bila periode yang sama dilihat dari aspek politik hukum Islam, maka justru pemerintahan Presiden Soeharto pada era awal pemerintahannya sangat akomodatif terhadap aspirasi hukum Islam di Indonesia yang ditandai lahirnya kebijakan-kebijakan pro hukum Islam dan lembaganya diantara UU No. 14 tahun 1970 tentang Pokok-Pokok Kekuasaan Kehakiman, UU No. 1 tahun 1974 tentang Perkawinan dan PP No. 9 tahun 1975 tentang Pelaksanaan Undang-Undang Perkawinan, PP no. 28 tahun 1977 tentang Pensertifikasian Tanah Wakaf Hak Milik dan kebijakan lainnya yang menyangkut bidang ibadah dan muamalah.Terjadinya akomodasi Orde Baru terhadap umat Islam dilandasi dengan fondasi bangunan politik negara dengan memakai konsep negara Pancasila dan mensejalankannya dengan nilai-nilai Islam. Kemudian konsep ini diikuti dengan membangun konsep kerukunan umat beragama di Indonesia dengan pendekatan top down. 
Jurna: Faktor-faktor yang Mempengaruhi Penyerapan Hukum Islam... | 161 Ketiga, politik hukum Islam di Indonesia dilihat dari faktor orang atau kelompok pendukung atau penentang yang terdiri atas nasionalis Islam, nasional religius dan nasional sekuler. Konflik nasionalis sekular dan nasionalis Islam menjelma ketika terjadi interaksi-interaksi antara pusatpusat kekuasaan dengan baik di tingkat infrastruktur maupun suprastruktur di tengah-tengah masyarakat dalam proses perumusan dasar negara dan proses legislasi hukum Islam di Indonesia. Pada masa Orde Baru dalam proses transformasi hukum Islam ke dalam hukum nasional pola-pola interaksi melahirkan dua kelompok penentang (nasionalis sekuler) dan pendukung (nasionalis Islam). Hal ini menentukan posisi syariah dalam UUD di Indonesia melahirkan aliran pemikiran yakni fundamentalis dan sekuler yang menyatakan bahwa syariah tidak compatible dengan UUD dan kelompok yang berpendapat bahwa syariah bisa berjalan seiring dengan UUD. Seiring dengan perkembangan zaman, jarak antara nasionalis religius dengan sekular semakin menipis dan bahkan kelompok nasionalis sekular dan nasionalis Islam melakukan sinergi tanpa harus terjebak dalam isu-isu menuju negara Islam dan Piagam Jakarta. Mencairnya hubungan antara dua kubu pemikiran di atas karena pergeseran paradigma berpikir umat Islam dari formalistik menuju substansif dari satu pihak dan perubahan pemahaman di tingkat infastruktur seperti partai politik, parlemen, ormas/LSM dan media massa dalam memeahami Islam dan kaitannya dengan negara. Hal ini juga ikut membantu perkembangan pemikiran hukum Islam yang sedang berkembang menuju penciptaan mazhab hukum Islam Indonesia.

Konfigurasi politik demokratis memberi ruang yang luas bagi transformasi hukum Islam ke dalam hukum nasional dengan karakter hukum yang responsif. Semakin demokratis suatu negara, maka akan semakin memperkecil potensi terjadinya konflik di antara nasionalis sekular dan nasionalis Islam. Sebagai standar untuk mengukur konfigurasi politik demokratis atau oteriter tergantung pada terpenuhnya pilar-pilar demokrasi di tingkat infrastruktur dan suprastuktur. Sedangkan untuk mengukur dari segi isi atau sifat sebuah produk hukum apakah responsif atau konservatif dapat dilihat dari sejauh mana aturan-aturan sejalan dengan hirarki perundang-undangan, sejalan dengan hukum Islam atau sekurang-kurangnnya tidak bertentangan dengan nilai-nilai ajaran Islam atau bertentangan dengan negara, Pancasila dan UUD 1945.

Transformasi nilai-nilai hukum Islam merupakan kewajiban konstitusional negara dalam membangun sistem hukum nasional Indonesia yang bersumber dari tiga sumber hukum yakni hukum adat, hukum Belanda, dan hukum Islam. Ketiga sub-sistem hukum ini 
merupakan the living law bagi masyarakat dan bangsa Indonesia. Proses transformasi hukum Islam menjadi hukum nasional dinamai dengan teori konstitusi (the constitution theory) dan teori akomodasi (the accomodation theory). Teori konstitusi yang dimaksud dalam kerangka politik hukum di sini adalah transformasi nilai-nilai hukum agama ke dalam hukum nasional Indonesia merupakan kewajiban berdasarkan konstitusi negara (obligation by constitution) untuk membangun sistem hukum nasional melalui makanisme kenstitusional yang demokratis. Teori ini dibangun berdasarkan argumentasi bahwa secara struktural UUD 1945 meletakkan posisi agama pada posisi yang tinggi. UUD 1945 mengakui dan menganut ide Ketuhanan Yang Maha Esa dalam kehidupan bermasyarakat, berbangsa dan bernegara. Ide Ketuhanan Yang Maha Esa itu tidak saja ditegaskan dalam dalam rumusan Pembukaan UUD 1945 yang menyebutkan secara eksplisit adanya pengakuan ini, tapi juga dengan tegas mencantumkan ide Ketuhanan Yang Maha Esa itu sebagai sila pertama dalam Pancasila. Dalam UU No. 1 tahun 1974 tentang Perkawinan pasal 2 (1) perkawinan adalah sah apabila dilakukan menurut masing-masing agama dan kepercayaannya itu.

Sedangkan teori akomodasi dibangun atas argumentasi bahwa negara berkewajiban untuk mengakomodasi seluruh subsistem hukum nasional ke dalam perundang-undangan negara dengan menggunakan tolak ukur hukum Islam sebagai hukum yang dianut mayoritas masyarakat Indonesia. Perkembangan ke arah adopsi semakin luas terhadap sistem hukum Islam yang berkesesuaian dengan dinamika kesadaran hukum dalam masyarakat Indonesia yang dituangkan dalam pelbagai bentuk peraturan perundang-undangan serta diwujudkan dalam esensi kelembagaan hukum yang dikembangkan dapat dikaitkan pula dengan pertimbangan-pertimbangan yang bersifat filosofis dan ketatanegaraan.

Bila dikaitkan teori konstitusi dengan teori akomodasi di atas dengan pemahaman mengenai konsep theistic democracy yang berdasarkan hukum ataupun konsep divine nomocracy yang demokratis yang berhubungan erat dengan penafsiran inovatif terhadap al-Quran yang mewajibkan untuk taat kepada Allah, taat kepada Rasulullah dan ulul 'amr (QS. Al-Nisa' (4) ayat 59). Oleh karena itu, konsep parlemen dalam pengertian modern dapat diterima dalam kerangka pemikiran hukum Islam melalui pemberlakuan norma-norma hukum Islam dengan dukungan otoritas kekuasaan umum yaitu melalui pelembagaannya menjadi peraturan perundang-undangan negara. 
Jurna: Faktor-faktor yang Mempengaruhi Penyerapan Hukum Islam... | 163

Produk Hukum Orde Baru yang Dihasilkan dari Penyerapan Hukum Islam

Hukum Agraria

Dengan diundangkannya UU No. 5 Tahun 1960 tentang UndangUndang Pokok Agraria (UUPA) sebenarnya masalah-masalah dasar yang menyangkut politik hukum agraria sudah diselesaikan dan dikristalisasikan dalam norma hukum pada Orde Lama pada tanggal 24 September 1960. Masalah yang dihadapi oleh pemerintah selanjutnya adalah bagaimana menindaklanjuti ketentuan-ketentuan yang sifatnya masih pokok itu. Tuntutan-tuntutan itu jika dibulatkan dapat dikaitkan dengan keharusan pemerintah membuat peraturan-peraturan lanjutan yang sesuai dengan ketentuan-ketentuan dan lingkup UUPA. Bahkan setelah 32 Tahun pada akhir tahun 1992, UUPA dinilai masih memiliki jiwa dan semangat yang relevan dengan tuntutan perkembangan zaman, sebab masih dapat menampung dan menyelesaikan bebagai masalah kekinian yang muncul. ${ }^{10}$ Relevansi tersebut terkait erat dengan beberapa asas yang dimilikinya seperti asas fungsi sosial, asas land-reform, dan asas perencanaan pembangunan tanah untuk kesejahteraan bersama.

Sejak diundangkannya Undang-Undang Pokok Agraria pada tanggal 24 September 1960, Peraturan Pemerintah yang dimaksudkan dalam pasal 49 ayat 3 Undang-Undang Pokok Agraria tersebut baru dapat dikeluarkan setelah 17 (tujuh belas) tahun kemudian yaitu dengan dikeluarkannya Peraturan Pemerintah No. 28 tahun 1977 yang dicatatkan dalam Lembaran Negara 1977 No. 38 tentang Perwakafan Tanah Milik pada tanggal 17 Mei 1977.

Dengan dikeluarkannya Peraturan Pemerintah No. 28 tahun 1977, maka melalui pasal 12 ditegaskan bahwa penyelesaian perselisihan sepanjang menyangkut persoalan perwakafan tanah disalurkan melalui Pengadilan Agama setempat sesuai dengan ketentuan perundangundangan yang berlaku. ${ }^{11}$ Atau dengan kata lain dengan dikeluarkannya PP No. 28 tahun 1977 kewenangan Pengadilan Agama semakin luas dan mantap.

Lahirnya Undang-Undang No. 1 Tahun 1974 tentang Perkawinan yang berlaku bagi seluruh warga negara Republik Indonesia tanggal 2 Januari 1974 untuk sebagian besar telah memenuhi tuntutan masyarakat Indonesia. Tuntutan ini sudah dikumandangkan sejak Kongres Perempuan Indonesia pertama tahun 1928 yang kemudian dikedepankan dalam

\footnotetext{
${ }^{10}$ Op.cit., Mahfud MD, hlm. 279

${ }^{11}$ Op.cit., Abdul Manan, hlm. 252
} 
kesempatan-kesempatan lainnya, berupa harapan perbaikan kedudukan wanita dalam perkawinan. Perbaikan yang didambakan itu terutama bagi golongan Indonesia Asli yang beragama Islam di mana hak dan kewajibannya dalam perkawinan tidak diatur dalam hukum yang tertulis. Hukum perkawinan orang Indonesia asli yang beragama Islam yang termaktub dalam kitab-kitab fiqh, menurut sistem hukum Indonesia tidaklah dapat digolongkan dalam kategori hukum tertulis, karena tidak tertulis dalam Peraturan Pemerintah.

Masalah-masalah yang menjadi pusat perhatian pergerakan wanita waktu itu adalah masalah: (1) perkawinan anak-anak (di bawah umur); (2) kawin paksa; (3) poligami; (4) talak yang sewenang-wenang. ${ }^{12}$ Setelah Indonesia merdeka langkah-langkah perbaikan diadakan oleh pemerintah antara lain mengeluarkan Undang-Undang tentang Pencatatan Nikah, Talak dan Rujuk tahun 1946. Setelah itu disusul dengan Peraturan Menteri Agama mengenai wali hakim dan tata cara pemeriksaan perkara pasif nikah, talak, dan rujuk di Pengadilan Agama. Namun demikian, perbaikan yang dituntut belumlah terpenuhi karena undang-undang dan peraturan-peraturan itu hanyalah mengenai formil belaka, tidak mengenai hukum materilnya yakni undang-undang yang mengatur tentang perkawinan itu sendiri.

Akhir tahun 1950 Menteri Agama saat itu, KH Wahid Hasyim membentuk sebuah Komite Penyelidik Peraturan Hukum Perkawinan, Talak dan Rujuk yang disingkat NTR dengan Surat Penetapan Menteri Agama RI No. B/4299 tanggal 1 Oktober $1950 .{ }^{13}$ Panitia ini bertugas meneliti dan meninjau kembali semua peraturan mengenai perkawinan serta menyusun Rancangan Undang-Undang (RUU) yang sesuai dengan perkembangan zaman.

Beberapa tahun setelah mengalami berbagai perubahan dan perkembangan baru, panitia yang diketuai oleh Mr. Teuku Moh. Hasan, ${ }^{14}$ dapat menyelesaikan sebuah rancangan undang-undang dimaksud. Selanjutnya, pada tahun 1958 Menteri Agama KH. Moh. Ilyas memperoleh persetujuan kabinet untuk mengajukan RUU tersebut ke

\footnotetext{
${ }^{12}$ Arso Sosroatmojo dan A. Wasit Aulawi, Hukum Perkawinan, (Jakarta: Bulan Bintang. 1975), hlm. 9

${ }^{13}$ K. Wantjik Salehlm, Hukum Perkawinan Indonesia, (Jakarta: Balai Aksara, 1987), hlm. 1

${ }^{14}$ Op.cit., Arso Sosroatmojo dan A. Wasit Aulawi, hlm. 9
} 
Jurna: Faktor-faktor yang Mempengaruhi Penyerapan Hukum Islam... | 165 parlemen. ${ }^{15}$ Namun pada sidang di Parlemen, Ny. Sumari dari Fraksi PNI mengajukan pula sebuah RUU perkawinan yang bersifat sekular. RUU inilah yang bersaing dengan RUU Perkawinan Islam 1954 (yang telah direvisi). Pembahasan RUU yang dimulai awal 1959 ini berlangsung sengit di Parlemen. Aktivis perempuan, Nani Soewondo, menyebutkan bahwa partai-partai Islam membela poligami, seakan-akan poligami adalah hal yang prinsip dari sebuah pernikahan. Bagi kubu partai Islam, persoalannya pembelaan poligami tak sekedar hal yang dibolehkan agama, tetapi lebih merupakan simbol pergulatan ideologis antara kubu Islam dan sekuler. Sebaliknya, Zaini Ahmad Noeh, mengatakan RUU Ny. Sumari tidak menyebutkan sedikitpun Peradilan Islam atau Hakim Islam, tetapi hanya peradilan sipil. Artinya RUU Ny. Sumari ini akan meniadakan peradilan Islam dalam persoalan perkawinan dalam Islam. ${ }^{16}$

Munculnya RUU ini menunjukkan adanya keretakkan di antara dua partai pendukung utama kabinet yaitu PNI dan NU. Meskipun dibentuk panitia ad hoc yang anggotanya terdiri dari pemerintah dan dua unsur yang bebeda, tapi panitia ini tidak pernah menemukan jalan keluar. Selanjutnya, rancangan undang-undang tersebut tidak menjadi UndangUndang karena DPR ketika itu telah dibekukan setelah adanya Dekrit Presiden Tanggal 5 Juli 1959.

Setelah mengalami beberapa perubahan, pada tanggal 1 April 1961 dibentuk sebuah panitia baru yang diketuai oleh Mr. Noer Persoetjipto. Pembentukan panitia baru ini dimaksudkan agar dapat bekerja keras lebih efektif lagi karena penitia lama diangap belum membuahkan hasil sebagaimana yang diharapkan. ${ }^{17}$

Penting untuk dicatat, bahwa antara tahun 1960 dan 1963 tercatat tiga kali pertemuan yang juga membicarakan masalah hukum perkawinan dan perundang-undangannya. Musyawarah Kesejahteraan Keluarga yang dilaksanakan pada tahun 1960 dan Konferensi BP4 Pusat tahun 1962 berturut-turut setiap tahun hingga 1973, serta seminar hukum oleh PERSAHI pada tahun 1963, semua mendesak kepada pemerintah agar Rancangan Undang-Undang Perkawinan yang sudah lama diajukan kepada DPR RI supaya segera dibahas lagi.18 Kemudian MPRS dengan

\footnotetext{
${ }^{15}$ Zaini Ahmad Noeh, "Perkembangan Hukum Keluarga Islam Setelah 50 Tahun Kemerdekaan (Catatan untuk Ulang Tahun Emas Departemen Agama)": Mimbar Hukum, No. 24 tahun VII Januari-Februari 1996, hlm. 12

${ }^{16}$ Ibid., hlm. 12-13

${ }^{17}$ Op.cit., Abdul Manan, hlm. 3 Lihat juga Op. cit., Arso Sosroatmojo dan A. Wasit Aulawi, hlm. 9

${ }^{18}$ Ibid., hlm. 10
} 
ketetapan No. XXVII tahun 1966 mengehendaki agar segera diundangkan Undang-Undang Perkawinan.19 Dengan adanya desakan dari berbagai pihak agar segera diwujudkan Undang-Undang Perkawinan, maka Pemerintah RI berusaha memenuhi dengan membentuk panitia yang membuat dua Rancangan Undang-Undang Perkawinan kemudian dibahas dalam sidang DPR RI. Pertama RUU tentang Pokok-Pokok Pernikahan Umat Islam dan yang kedua RUU tentang Pokok Pokok Perkawinan. RUU tentang Pokok-Pokok Perkawinan Umat Islam tidak dapat disahkan oleh DPR pada tahun 1968 karena satu fraksi menolak, 2 fraksi tidak menunjukkan sikap, 13 setuju. Setelah dibentuk DPR RI hasil pemilu tahun 1971, maka semua RUU tentang Perkawinan dikembalikan kepada pemerintah. ${ }^{20}$

Dalam waktu kurun lebih lanjut, simposium ISWI (Ikatan Sarjana Wanita Indonesia) tanggal 29 Januari 1972 memberikan saran kepada pengurusnya agar memeperjuangkan kembali Undang-Undang Perkawinan untuk diberlakukan kepada seluruh warga negara Indonesia.21 Adapun penilaian ISWI tentang materi hukum perkawinan antara lain sebagai berikut: (1) makin dirasakan mendesaknya keperluan akan sesuatu UU perkawinan untuk Indonesia; (2) simposium mencatat adanya perkembangan pendekatan yang besar dalam asas-asas perkawinan di antara berbagai umat beragama, sehingga diharapkan dalam pembentukan Undang-Undang Perkawinan nanti soal materi tidak lagi merupakan problem pokok; (3) yang menjadi halangan besar adalah belum adanya kesesuaian mengenai sistem antara differensiasi (masingmasing golongan mempunyai undang-undangnya sendiri) atau univikasi (satu undang-undang untuk semua). ${ }^{22}$

Sejalan dengan desakan ISWI, Badan Musyawarah Organisasiorganisasi Wanita Islam Indonesia pada tanggal 22 Februari 1972 juga mendesak pemerintah mengajukan kembali kedua RUU tentang Perkawinan yang dahulu dikembalikan oleh DPR-GR kepada pemerintah, agar dibahas kembali oleh DPR RI. ${ }^{23}$ Adapun sistem pemikiran rancangan undang-undang lama adalah adanya satu undang-undang pokok, selanjutnya bagi masing-masing golongan diadakan undang-undang organiknya (differensiasi dalam univikasi). Organisasi Islam Wanita Indonesia condong pada pemikiran masing-masing golongan mempunyai

${ }^{19}$ Op.cit., K. Wantjik Salehlm, hlm. 2

${ }^{20}$ Ibid., hlm. 5 Lihat juga Op.cit., Arso Sosroatmojo dan A. Wasit Aulawi, hlm. 10

${ }^{21}$ Op.cit., K. Wantjik Salehlm, hlm. 2

${ }^{22}$ Op.cit., Arso Sosroatmojo dan A. Wasit Aulawi, hlm. 22-23

${ }^{23}$ Ibid. hlm. 10 
Jurna: Faktor-faktor yang Mempengaruhi Penyerapan Hukum Islam... | 167 undang-undangnya sendiri (differensiasi). ${ }^{24}$ Akhirnya Himpunan Mahasiswa Islam (HMI) membicarakan kembali tentang hukum Perkawinan Umat Islam di Indonesia dalam acara sarasehan yang dilaksanakan pada tanggal 11 Februari 1973 di Jakarta dan mengharapkan agar pemerintah segera mengajukan kembali RUU tentang Perkawinan kepada DPR RI untuk dibahas kembali dan dilaksanakan sebagai undangundang yang diberlakukan untuk seluruh warga negara Indonesia.

Dengan amanat Presiden RI tanggal 31 Juli 1973 No. R.02/PU/VII/1973 kepada pimpinan DPR RI disampaikan UndangUndang Perkawinan yang terdiri dari XIV bab 73 pasal. Keterangan pemerintah tentang RUU Perkawinan ini disampaikan oleh Menteri Kehakiman pada tanggal 30 Agustus 1973. Banyak cara dan usulan yang disampaikan masyarakat kepada DPR RI sehubungan dengan RUU tentang Perkawinan ini. Usul-usul dan saran-saran tersebut disampaikan masyarakat kepada DPR RI sehubungan dengan adanya anggapan bahwa ada beberapa pasal dalam RUU Perkawinan yang diajukan oleh pemerintah kepada DPR RI itu tidak sesuai dengan kondisi masyarakat Indonesia yang religius dan bertentangan dengan norma agama yang dianutnya.

Pada tanggal 16 Agustus 1973 Pemerintah kembali mengajukan Rancangan Undang-Undang tersebut kepada DPR. Pemandangan umum atas RUU Perkawinan ini diberikan oleh wakil-wakil fraksi pada tanggal 17-18 September 1973. Jawaban pemerintah diberikan oleh Menteri Agama RI pada tanggal 27 September 1973, yang pokoknya pemerintah mengajak semua pihak terutama anggota DPR RI untuk mencari jalan ke luar terhadap beberapa persoalan hukum yang terdapat dalam RUU Perkawinan itu belum selesai. Sebulan sebelum diajukan rancangan Undang-undang tersebut timbul reaksi keras dari kalangan umat Islam. RUU tersebut sangat bertentangan dengan ajaran-ajaran Islam dan ada anggapan yang lebih keras lagi, RUU tersebut ingin mengkristenkan Indonesia. Sementara itu di lembaga legislatif, FPPP adalah fraksi yang paling keras menentang RUU tersebut, karena bertentangan dengan fiqh. Kamal Hasan menggambarkan bahwa semua ulama baik dari kalangan tradisional maupun modernis, dari Aceh sampai Jawa Timur menolak RUU tersebut. ${ }^{25}$

\footnotetext{
${ }^{24}$ Ibid. hlm. 22-25

${ }^{25}$ Kamal Hasan, Modernisasi Indonesia; Respons Cendekiawan Muslim. (Jakarta: Lingkaran Studi Indonesia, 1987), hlm. 190
} 
Melalui pendekatan (lobbying) antara tokoh-tokoh Islam dengan pemerintah, akhirnya RUU tersebut diterima oleh kalangan Islam dengan mencoret pasal-pasal yang bertentangan dengan ajaran Islam. Sampai di sini tidak berlebihan apabila menyebut bagaimana upaya FPPP untuk mempertahankan eksistensi hukum Islam. Agar pembahasannya berjalan lancar, maka dicapai kesepakatan antara fraksi PPP dengan fraksi ABRI yang isinya: Hukum agama Islam dalam perkawinan tidak akan dikurangi atau diubah, maka alat-alat pelaksanaannya tidak akan dikurangi atau diubah, tegasnya UU No. 22 tahun 1946 dan UU No. 14 tahun 1970 dijamin keberlangsungannya. Hal-hal yang bertentangan dengan agama Islam dan tidak mungkin disesuaikan dengan undang-undang ini dihilangkan (didrop). Mengenai perceraian dan poligami diusahakan perlu ketentuan-ketentuan guna mencegah terjadinya kesewenang-wenangan.26 Jelaslah di dalam kesepakatan tersebut menunjukan betapa kuatnya posisi FPPP sebagai wakil umat Islam dalam memperjuangkan agar UU Perkawinan tidak bertentangan dengan syari'at Islam. Adapun pasal-pasal yang dicoret tersebut adalah pasal 11 mengenai sistem parental dan perkawinan antar agama, pasal 13 mengenai pertunangan, pasal 14 mengenai tata cara gugatan perkawinan dan pasal 62 mengenai pengangkatan anak. ${ }^{27}$

Untuk memperlancar usaha pembahasan RUU Perkawinan, DPR RI membentuk panitia kerja yang anggotanya terdiri dari wakil-wakil fraksi yang bertugas membicarakan secara mendalam usul-usul amandemen bersama pemerintah yang dalam hal ini diwakilkan oleh Menteri Kehakiman dan Menteri Agama. Atas permintaan panitia kerja tersebut, Menteri Agama menguraikan arti pentingnya norma agama dimasukkan ke dalam Undang-Undang Perkawinan yang akan disahkan itu. Menteri Agama menguraikan norma-norma perkawinan tersebut dalam al-Qur'an dan sunnah yang berlaku bagi umat Islam, Menteri Agama juga menguraikan dasar-dasar perkawinan dalam agama Hindu yang diambil dari buku The Law of Menuel jilid 25 karangan Max Muler dan dari kitab Manaha Dharma Satwa. Menteri Agama juga menguraikan dasar-dasar perkawinan dalam agama Budha yang diambil dari kitab Tripitaka. Dasar-dasar perkawinan agama Khatolik diambil dari kitab Perjanjian Lama dan Baru.

${ }^{26}$ Rachmadi Usman, Perkembangan Hukum Perdata dalam Dimensi Sejarah dan Politik Hukum di Indonesia. (Jakarta: Grafiti, 2003), hlm. 196

${ }^{27}$ Abdullah Aziz Thaba, Islam dan Negara dalam Politik Orde Baru, (Jakarta: Gema Insani Perss, 1996), hlm. 261 
Jurna: Faktor-faktor yang Mempengaruhi Penyerapan Hukum Islam... | 169

Akhirnya setelah mengalami perubahan-perubahan atas amandemen yang masuk dalam panitia kerja, dengan menghapuskan pasal-pasal yang menimbulkan keberatan di kalangan umat Islam, pada tanggal 22 Desember 1973 melalui fraksi-fraksi DPR, RUU tersebut disetujui untuk disahkan. Pada tanggal 2 Januari 1974 RUU tentang perkawinan disahkan DPR menjadi Undang-Undang No. 1 tahun 1974 tentang perkawinan yang dicatatkan dalam Lembaran Negara No. 1 tahun 1974 Tambahan Lembaran Negara No. 3019/1974 yang selanjutnya berlaku efektif sejak tanggal 1 Oktober 1975.28 Adapun isi dari UndangUndang No. 1 tahun 1974 terdiri dari 14 bab dan 67 pasal. Kehadiran UU No. 1 tahun 1974 ini disusul dengan lahirnya peraturan pelaksananya dengan Peraturan Pemerintah No. 9 tahun 1975 tentang Pelaksanaan UU No. 1 tahun 1974. Kemudian disusul pula dengan keluarnya Peraturan Menteri Agama dan Menteri Dalam Negeri. Bagi umat Islam diatur dalam Permenag No. 3 tahun 1975 dan No. 4 tahun 1975, kemudian diganti dengan Peraturan Menteri Agama No. 2 tahun 1990. Bagi selain beragama Islam diatur dalam Permendagri No. 221a tahun 1975, tanggal 1 Oktober 1975 tentang Pencatatan Perkawinan dan Perceraian pada Kantor Catatan Sipil. ${ }^{29}$

Pada tahun 1983 lahir pula Peraturan pemerintah No. 10 yang mengatur tentang Izin Perkawinan dan Perceraian bagi Pegawai Negeri Sipil. Peraturan yang ditetapkan tanggal 23 April 1983 ini berisi 23 pasal. Kemudian pada tahun 1990 keluar PP No. 45 yang berisikan perubahan PP No. 10 tahun 1983 yang isinya memuat beberapa pasal yang ada dalam PP No. 10 tahun 1983. PP No. 45 tahun 1990 ini hanya berisi dua pasal.

Menarik untuk dicatat dengan disahkannya UU Perkawinan No 1 tahun 1974, hukum Islam memasuki fase baru dengan apa yang disebut fase taqnin (fase pengundangan). Banyak sekali ketentuan-ketentuan fiqh Islam tentang perkawinan ditransformasikan ke dalam UU tersebut kendati dengan memodifikasi di sana sini.

Berkaitan dengan perkembangan hukum Islam dalam masa ini tidak ada yang signifikan dalam kaitannya dengan political will pemerintah. Agaknya perkembangan hukum Islam baik secara kelembagaan dan produk-produk pemikiran semakin kentara pada era

\footnotetext{
${ }^{28}$ Op.cit., Rachmadi Usman, hlm. 198

29 Ichtijanto S.A, Prospek Peradilan Agama sebagai Peradilan Negeri dalam Sistem Politik Hukum Indonesia dalam Amrullah Ahmad. Editor, Dimensi Hukum Islam dalam Sistem Hukum Nasional. (Jakarta: Gema Insani Press, 1996), hlm. 185
} 
akomodatif seperti diundangkannya Undang-Undang No. 7 tahun 1989 tentang Peradilan Agama.

Undang-Undang No. 1 tahun 1974 tentang Perkawinan disahkan pada tanggal 2 Januari 1974 sebagai hukum materil Pengadilan Agama. Namun Pengadilan Agama belum mempunyai hukum formil, sehingga setiap putusan hakim Pengadilan Agama harus mendapatkan pengukuhan dari Peradilan Umum/Pengadilan Negeri agar keputusan Pengadilan Agama dapat dilaksanakan dan memiliki kekuatan hukum. Keadaan ini membuat Pengadilan Agama jauh dari sistem peradilan yang otonom. Rancangan Undang-Undang Peradilan Agama akan menghentikan perlunya pengukuhan semacam itu. Pengadilan Agama akan mempunyai kekuatan hukum sendiri dan juga sarana administrasi untuk melaksanakan keputusannya sendiri. Kedudukannya yang berada di bawah Pengadilan Negeri itu akan dihapuskan. Rancangan Undang-Undang tentang Peradilan Agama telah ada semenjak KH. Muhammad Dahlan dan Mukti Ali sebagai menteri Agama, kendati demikian baru ditanggapi oleh pemerintah dengan dikeluarkannya Keputusan Menteri Agama No. G164-PR-09.03/1982 yang berisi keputusan untuk membentuk tim pembahas dan penyusun rancangan tersebut dan diketuai oleh Dr. Bustanul Arifin.

RUU Peradilan Agama merupakan hasil pembahasan ahli hukum baik dari universitas umum maupun agama. Sewaktu RUU itu sedang dibicarakan di parlemen, timbullah reaksi di luar parlemen. Menteri Agama Munawir Sjadzali telah ditanya apakah rancangan itu adalah tanda bahwa Indonesia sedang menuju ke arah negara Islam, yang dengan tangkas dijawab oleh Munawir Sjadzali "bahwa negara seperti Singapura, Philipina, Sri Langka, Muang Thai mempunyai pengadilan-pengadilan agama (mahkamah syari'ah). Beliau menambahkan bahwa perancangan undang-undang itu tidak saja dilakukan oleh Departemen Agama melainkan juga dilakukan oleh Mahkamah Agung, karena hal itu hanyalah kelanjutan dari Undang-Undang Pokok Kekuasaan Kehakiman UU No. 14 Tahun 1970. Munawir Sjadzali juga ditanyai apakah ia berpendapat bahwa golongan agama-agama lainnya juga menghandaki undang-undang yang sama, yang kemudian beliau jawab: "bahwa soal itu akan dibicarakan dikemudian hari. Beliau menambahkan misalnya pada agama Hindu, orang harus bertanya secara jujur pada diri sendiri apakah pengadilan-pengadilan yang dahulu berdasarkan agama ataukah adat. Beliau menjamin bahwa bagaimanapun keberadaan pengadilan agama 
Jurna: Faktor-faktor yang Mempengaruhi Penyerapan Hukum Islam... | 171 merupakan kebutuhan sejarah dan tidak akan membahayakan kepentingan-kepentingan golongan bukan Islam". ${ }^{30}$

Reaksi keras baik yang mendukung maupun yang menentang datang dari berbagai kalangan. Dukungan muncul dari kalangan Islam, sedangkan reaksi yang keras datang dari kalangan Kristen dan tidak ketinggalan kalangan Khatolik seperti Franz Magnis Suseno dan Leo Soekanto. ${ }^{31}$

Pendapat Franz ini mendapat tanggapan dari Prof. Dr. HM. Rasjidi. ${ }^{32}$ Beliau mengatakan bahwa pendapat Franz tidak benar mengenai dengan disahkannya RUU PA berarti sebagian dari materi peradilan dalam masyarakat Indonesia diserahkan dari tangan negara ke tangan badan-badan pihak non negara. Menurut UU No. 14 tahun 1970 tentang Kekuasaan Pokok-Pokok Kehakiman menjelaskan bahwa di Indonesia mempunyai empat lingkungan peradilan yaitu Peradilan Umum yang dilaksankan oleh Pengadilan Negeri, peradilan khusus seperti Peradilan Militer, Peradilan Tata Usaha Negara dan Peradilan Agama. Penyebutan peradilan khusus oleh penjelasan UU No. 14 tahun 1970 itu tidaklah dimaksudkan untuk mengistimewakan warga negara yang diadili, melainkan hanya menunjukan perbedaaan ketiga peradilan itu dari peradilan umum yang memiliki kompetensi yang lebih luas dan umum, baik mengenai persoalan perdata maupun pidana. Dengan di bawah pengawasan Mahkamah Agung, keempat lingkungan peradilan itu melakukan kekuasaan kehakiman dalam Negara Kesatuan Republik Indonesia dan Peradilan Agama adalah bagian dari peradilan negara dalam sistem peradilan nasional. ${ }^{33}$ Melalui majalah Khatolik Hidup memuat berita dan tulisan-tulisan yang menentang rancangan undangundang itu dan berpendapat bahwa rancangan itu bersifat tidak adil, memaksakan undang-undang Islam kepada masyarakat Indonesia. Jadi memaksakan pemerintahan agama atas demokrasi dan mengencam ideologi negara Pancasila. Persekutuan gereja-gereja Indonesia (PGI) melalui sepucuk surat kepada parlemen juga menyetakan

${ }^{30}$ Muhammad Atho Mudzhar, Fatwa-Fatwa Majelis Ulama Indonesia (Sebuah Studi tentang Pemikiran Hukum Islam di Indonesia 1975-1988), (Jakarta: INIS, 1993), hlm. 48-51

${ }^{31}$ Franz Magnis Suseno, Seputar Rencana Undang-Undang Peradilan Agama Prof. Dr. HM Rasjidi Menjawab Magnis Suseno, ( Jakarta: Dewan Dakwah Islamiyah Indonesia Pusat, tt), hlm. 35

${ }^{32}$ HM. Rasjidi, Soal Peradilan Agama, (Jakarta: Dewan Dakwah Islamiyah Indonesia Pusat, 1989), hlm. 9

${ }^{33}$ Ibid. hlm. 9 
kekhawatirannya atas rancangan undang-undang mengenai Peradilan Agama itu. Dikatakannya bahwa rancangan undang-undang itu dapat mengganggu konsensus nasional mengenai Pancasila sebagai satusatunya ideologi negara. ${ }^{34}$ Politik Kristen bergerak baik dari dalam jajaran pemerintahan, partai politik dan para intelektual mereka dari dalam jajaran pemerintahan misalnya memperlambat proses pembicaraan RUU PA dengan berbagai alasan yang terkadang sulit diterima oleh akal sehat.

Reaksi-reaksi yang menentang juga datang dari pihak bukan Islam seperti halnya juga datang dari pihak Islam. Soeprapto, seorang muslim dan mantan Gubernur Jakarta, waktu itu sebagai ketua Majelis Permusyawaratan Rakyat dalam sepucuk surat kepada Perlemen menyatakan bahwa rancangan undang-undang Peradilan Agama merupakan deskriminasi terhadap golongan bukan Islam dan bersifat tidak konstitusional. Bahkan menurut beliau UU No. 14 tahun 1970 tentang Pokok-Pokok Kekuasaan Kehakiman yang berisikan peraturan tentang pengakuan terhadap Pengadilan Agama agar dicabut. Amir Machmud, seorang muslim lainnya dan mantan Menteri Dalam Negeri serta mantan ketua MPR menyetujui pendapat Soeprapto dan mengatakan bahwa hukum Islam tidak dapat dipersatukan dalam hukum nasional yang seharusnya hanya didasarkan pada Pancasila. ${ }^{35}$ Sementara itu, reaksireaksi yang agak kurang keras menentang datangnya dari kalangan ilmuan yang umumnya menganggap perlu diadakannya peraturanperaturan tersendiri bagi kaum muslimin mengenai perkara-perkara pernikahan, perceraian, kewarisan dan perwakafan. Akan tetapi tidak dapat menyetujui gagasan untuk mengadakan peradilan agama secara tersendiri. Mereka berpendapat bahwa untuk membentuk sisem kesatuan peradian di Indonesia, maka kekuasaan peradilan harus berada di tangan satu badan peradilan. ${ }^{36}$

Reaksi-reaksi keras itu baru mulai reda setelah Presiden Soeharto menegaskan bahwa RUU tersebut dimasukan untuk melindungi kaum muslim Indonesia dalam aspek-aspek yang berkaitan dengan ibadah, sebagaimana yang dijamin oleh pasal 29 UUD $1945 .{ }^{37}$ Oleh karena itu,

\footnotetext{
${ }^{34}$ Op.cit., Muhammad Atho Mudzhar, hlm. 49 Munawir Sjadzali, Islam dan Tata Negara: Ajaran, Sejarah dan Pemikiran, (Jakarta: UI Press, 1991), hlm. 101-102 Lihat juga Dadan Muttaqien (ed), Peradilan Agama dan Kompilasi Hukum Islam dalam Tata Hukum Indonesia. (Yogyakarta: UII Press, 1999), hlm. 4-5

${ }^{35}$ Ibid., hlm. 50

${ }^{36}$ Ibid., hlm. 51

${ }^{37}$ Basiq Djalil, Peradilan Agama di Indonesia, (Jakarta: Kencana Prenada Group, 2006), hlm. 27
} 
Jurna: Faktor-faktor yang Mempengaruhi Penyerapan Hukum Islam... | 173 sangatlah tepat pandangan Menteri Kehakiman Islamil Shaleh ketika itu yang dimuat dalam harian Kompas 1 Juni 1989 tentang wawasan pembangunan nasional yang melihat kenyataan dalam masyarakat Indonesia Bhineka Tunggal Ika. ${ }^{38}$

Sementara itu, di dalam parlemen perdebatan mengenai rancangan undang-undang itu rupanya tidak begitu panas, sedikitnya apa yang tampak dipermukaan. ${ }^{39}$ Mungkin karena kepekaan masalahnya, maka tiap fraksi dalam parlemen berusaha menahan diri untuk mengadakan pernyataan yang keras. Partai politik yang cukup intens mendukung dan mengawal rancangan undang-undang ini adalah Partai Persatuan Pembangunan (PPP). Fraksi yang didukung pemerintah, Golkar juga menyokong dengan sedikit pertanyaan mengenai beberapa pasal untuk dijelaskan pemerintah. Fraksi ABRI menyetujui rancangan dengan beberapa usul perubahan kecil. Satu-satunya fraksi yang tidak menyatakan sokongannya adalah koalisi golongan nasionalis sekular dan golongan Kristen, PDI. Fraksi ini tidak nyata-nyata menolak rancangan itu, tetapi secata tidak langsung menolaknya dengan mempertanyakan manfaat undang-undang itu, karena sifatnya deskriminatif dan tidak konstitusional. Sebaliknya, kedudukan pemerintah adalah bersatu dan jelas. Menteri Agama, Munawir Sjadzali, Menteri Kehakiman Ismail Shaleh, dan Ketua Hakim Agung Ali Said, semuanya menyatakan dengan jelas pendapatnya bahwa undang-undang itu adalah konstitusional dan selaras dengan cita-cita untuk mencapai sistem kesatuan peradilan di Indonesia. Kemudian Presiden Soeharto sendiri memberikan jaminan bahwa undang-undang itu tidak akan bersifat deskriminatif terhadap kaum bukan Islam dan RUU PA itu merupakan implementasi dari UUD 1945 dan pancasila dan hal itu tidak ada hubungannya sama sekali dengan Piagam Jakarta. ${ }^{40}$

Memperjuangkan RUU PA ketika itu amatlah berat, karena kenyataannya musuh Islam tidak saja berasal dari luar Islam, tapi juga berasal dari sekelompok Islam sendiri yang tidak ingin memperjuangkan diberlakukannya syari'at. Atas usaha keras pemerintah (Depatemen Agama) dan dukungan dari fraksi-fraksi di DPR, pada 29 Desember 1989 RUU tersebut disahkan menjadi Undang-Undang No. 7 tahun 1989

\footnotetext{
${ }^{38}$ Daud Ali, Hukum Islam dan Peradilan Agama, (Jakarta: CPT. RajaGrafindo Persada, 1997), hlm. 259

${ }^{39}$ Op.cit., Dadan Muttaqien (ed), hlm. 5

${ }^{40}$ Nadirsyah Hosen. Shari'a \& Constitutional Reform in Indonesia, Singapor: Institute of Southeas Asian Studies. 2007. hlm. 74. Abdul Halim. Peradilan Agama dalam Politik Hukum di Indonesia. Jakarta: PT. RajaGrafindo Persada, 2002. hlm. 137
} 
tentang Peradilan Agama dengan hanya perubahan kecil dari rancangan semula. ${ }^{41}$ Keberadaan UU PA menjadi sangat signifikan jika diletakkan dalam konteks negara-negara Islam. Dengan diundangkannya undangundang ini, kedudukan Peradilan Agama semakin kokoh dan lebih terhormat lagi. Munawir sebagaimana yang dikutib dalam Iskandar Ritonga menyebutkan bahwa Undang-Undang Peradilan Agama merupakan sebuah lompatan besar-dari segi perundang-undangan adalah lompatan seratus tahun dan dari segi hukum substantif adalah lompatan seratus windu. ${ }^{42}$

\section{Kompilasi Hukum Islam}

Ide Kompilasi Hukum Islam timbul setelah beberapa tahun Mahkamah Agung membina bidang teknis yustisial Peradilan Agama. Tugas pembinaan ini pada saat itu didasari oleh Undang-Undang No. 14 tahun 1970 tentang Ketentuan-Ketentuan Pokok Kekuasaan Kehakiman pasal 11 ayat (1) menyatakan organisasi, administrasi dan keuangan pengadilan dilakukan oleh departemen masing-masing, sedangkan pembinaan yustisial dilakukan oleh Mahkamah Agung. Meskipun undang-undang tersebut diterapkan pada tahun 1970, namun pelaksanaannya di lingkungan Pengadilan Agama baru tahun 1983 setelah penandatanganan Surat Keputusan Bersama (SKB) Ketua Mahkamah Agung dan Menteri Agama No. 01,02, 03 dan 04/SK/1-1983. SKB ini merupakan jalan pintas, sambil menunggu keluarnya undang-undang tentang susunan, kekuasaan dan acara Peradilan Agama yang merupakan peraturan pelaksana UU No. 14 tahun 1970 bagi Lingkungan Peradilan Agama yang pada saat itu masih dalam tahap penyusunan.

Pada tahun 1985 bertempat di hotel Ambarukmo Yogyakarta ada peristiwa bersejarah, yakni penandatangan naskah proyek Kompilasi Hukum Islam oleh Ketua Mahkamah Agung Ali Said dengan Mentri Agama Munawir Sjadzali. Latarbelakang penyelenggaraan proyek ini sangat jelas yakni memberikan kepastian hukum bagi para justisiabel dan hakim-hakim agama dalam perkara perdata tertentu di kalangan umat Islam Indonesia. Adalah kenyataan meskipun sejarah Peradilan Agama di Indonesia sudah berusia lebih dari satu abad, tapi hukum materialnya masih bervariasi atau berserak di dalam kitab-kitab fiqh yang dalam memberi solusi terhadap masalah hukum tidak selalu sama. Kenyataan ini

\footnotetext{
${ }^{41}$ Op.cit., Munawir Sjadzali, hlm. 99

${ }^{42}$ Iskandar Ritonga, Membumikan Hukum Islam di Nusantara (Biografi dan Pemikiran Lima Tokoh Hukum Islam Indonesia, (Jakarta: Quantum, 2000), hlm. 175-176
} 
Jurna: Faktor-faktor yang Mempengaruhi Penyerapan Hukum Islam... | 175 memberi dampak kurang baik bagi Penyelenggara Peradilan Agama yaitu tidak adanya kepastian atau kelugasan hukum. Sering terjadi bahwa terhadap satu kasus yang sama, lahir putusan (vonis) yang berbeda dari hakim yang berbeda pula; tepatnya putusan seorang hakim di satu tempat atau waktu terhadap satu jenis kasus sering berbeda dengan putusan hakim yang lain di tempat lain atau waktu yang lain. Dipandang dari sudut prinsip menegakkan kepastian hukum bagi suatu lembaga peradilan, maka kenyataan tersebut merupakan kenyataan yang tidak sehat. Untuk mengatasi hal itu diperlukan adanya satu buku hukum yang menghimpun semua hukum terapan yang berlaku bagi lingkungan Peradilan Agama yang dapat dijadikan pedoman oleh para hakim dalam melaksankan tugasnya, untuk menjamin akan adanya kesatuan dan kepastian hukum. ${ }^{43}$

Meskipun Kompilasi Hukum Islam telah rampung disusun dan disepakati pada bulan Maret 1988, tetapi pemberian baju hukumnya dalam bentuk Inpres baru diwujudkan pada 10 Juni 1991. Penundaan pemberian baju hukum sampai tiga tahun lebih ini, menurut mantan Menteri Agama Munawir Sjadzali disebabkan karena terhadap paket hukum material tersebut masih diperlukan wadah yang secara yuridis lebih kuat yaitu UU tentang Peradilan Agama. Atau dengan kata lain, Kompilasi Hukum Islam itu baru akan diberlakukan atau diberi baju hukum jika sudah ada UU tentang Peradilan Agama. Demikianlah hasil Proyek Kompilasi Hukum Islam pada tahun 1988 disimpan dulu dan pada tahun 1989 DPR dan pemerintah mulai membahas RUU PA.

Gagasan penyusunan Kompilasi Hukum Islam terealisir dengan lahirnya proyek kerjasama antara Mahkamah Agung dan Departemen Agama yang ditetapkan dengan Surat Kepuusan Bersama Ketua Mahkamah Agung dan Menteri Agama tentang Penunjukan Pelaksana Proyek Pembangunan Hukum Islam melalui Yurisprudensi No. 07/KMA/1985 dan No. 25 tahun 1985 tanggal 21 Maret $1985 .{ }^{44}$ Sebagai Pemimpin Umum Pelaksana Proyek ini adalah Dr. H. Bustanul Arifin, SH

\footnotetext{
43 Tim Direktorat Pembinaan Badan Peradilan Agama, Kompilasi Hukum Islam di Indonesia. Direktorat Pebinaan Badan Peradilan Agama Departemen Agama. 1991.1992, hlm. 139 Lihat juga Op.cit., Basiq Djalil, hlm. 110 Lihat juga Op.cit., Dadan Muttaqien (ed), hlm. XV-XVI

${ }^{44}$ Rifyal Ka'bah, Hukum Islam di Indonesia, (Jakarta: Universitas Yarsi, 1999), hlm. 56 Lihat Op.cit., Basiq Djalil, hlm. 111
} 
Ketua Muda Mahkamah Agung RI Urusan Lingkungan Peradilan Agama. $^{45}$

Usaha yang dilakukan oleh kelompok ini melalui empat tahapan yaitu: pertama, pengkajian kitab-kitab fiqh dengan mengumpulkan kitabkitab fiqh sebanyak 38 kitab yang dimintakan kepada 10 IAIN yang ditunjuk dalam waktu 3 bulan mulai tanggal 7 Maret sampai dengan 21 Juni 1985 untuk mengkaji dan meminta pendapatnya disertai dengan argumentasi atau dalil hukumnya.46 Selain pengkajian kitab-kitab fiqh tersebut, juga diambil hasil-hasil fatwa yang berkembangan di Indonesia, seperti Fatwa Majelis Ulama Indonesia (MUI), Nahdlatul Ulama (NU), Majelis Tarjih Muhammadiyah dan lain-lain. Kedua, wawancara dengan ulama di seluruh Indonesia. Pelakasanaan diambil dari 10 lokasi yaitu Banda Aceh, Medan, Padang, Palembang, Jawa Tengah, Jawa Barat, Surabaya, Ujung Pandang, Mataram, dan Banjarmasin. Ketiga, jalur yurisprudensi. Penggarapan jalur ini dilaksanakan oleh Direktorat Pembinaan Badan Peradilan Agama yang dihimpun dalam 16 buku. Keempat, jalur studi perbandingan dilaksanakan di Timur Tangah, yaitu di Maroko tanggal 28 dan 29 Oktober 1986, di Turki pada tanggal 1 dan 2 November 1986, di Mesir pada tanggal 3 dan 4 November 1986. Hasil studi banding tersebut meliputi sistem peradilan, masuknya syariah law dalam hukum nasional dan sumber hukum ahwal al-syakhshiyah (hukum keluarga) yang menyangkut kepentingan muslim.

Sebagai puncak kegiatan proses dan perumusan KHI setelah mengumpulkan data, pengolahan dan penyusunan draft oleh tim yang ditunjuk, diadakan Lokakarya Nasional dalam rangka menyempurnakan kerja tim. Lokakarya ini dimaksud untuk menggalang ijma' ahli-ahli hukum Islam dan hukum umum Indonesia. Lokakarya ini berlangsung dari tanggal 2-6 Februari 1988, dihotel Kartika Candra Jakarta yang diikuti oleh 124 orang peserta dari seluruh Indonesia. Berdasarkan hasil lokakarya tesebut, berbagai pihak menghendaki kompilasi tersebut dituangkan dalam bentuk undang-undang. Namun di sisi lain, ada kekhawatiran apabila harus ditempuh melalui DPR, akan semakin sulit dan memakan waktu yang berlarut-larut. Ada juga yang berkeinginan agar Kompilasi Hukum Islam dituangkan dalam Peraturan Pemerintah atau putusan presiden. Akhirnya dengan potong kompas Mahkamah Agung bekerjasama dengan Departemen Agama, atas restu Presiden

\footnotetext{
${ }^{45}$ Keputusan Bersama Ketua Mahkamah Agung dan Menteri Agama tanggal 21 Maret 1985 No. 07/KMA/1985 dan No. 25 tahun 1985 tentang Penunjukan Pelaksana Proyek pembangunan Hukum Islam Melalui Yurisprudensi.

${ }^{46}$ Ibid., hlm. 114
} 
Jurna: Faktor-faktor yang Mempengaruhi Penyerapan Hukum Islam... | 177

Soeharto pada tanggal 10 Juni 1991 disahkan Kompilasi Hukum Islam dalam bentuk Instruksi Presiden No. 1 tahun 1991. Sejak saat itu, Kompilasi Hukum Islam berlaku sebagai hukum material di lingkungan Peradilan Agama di Indonesia.

Lebih lanjut, dengan disahkannya Kompilasi Hukum Islam melalui Inpres No. 1 Tahun 1991 adalah merupakan puncak pemikiran fiqh Indonesia. Pernyataan ini didasarkan pada proses perumusan Kompilasi Hukum Islam tersebut diseminarkan dalam lokakarya nasional yang didatangi oleh tokoh ulama fiqh dari berbagai organisasi Islam, ulama fiqh dari perguruan tinggi, dari masyarakat umum ikut membahasnya. Sehingga patut dinilai sebagai ijma' ulama Indonesia.

\section{PENUTUP}

Berdasarkan uraian di atas dapat disimpulkan bahwa faktor yang mempengaruhi penyerapan hukum Islam di Indonesia tidak bisa terlepas dari pergumulan dan ketegangan abadi dalam memosisikan relasi agama (syariat Islam) dan negara, antara proyek sekularisasi dan Islamisasi negara dan masyarakat. Ketegangan ini terjadi dalam dua tataran penting yang berbeda. Pertama, tataran scholastik atau bersifat teoritik-idealistik. Kedua, tataran realistic-politic atau ideologi-empirik. Perdebatan dalam rangka ideologis tersebut berimplikasi pada perdebatan ranah hukum. Konflik dan pergumulan dalam ranah ini terjadi sebagai konsekuensi dari: pertama, dilihat dari segi pluralitas jenis penduduk dan sistem hukum yang berlaku di masyarakat sejak zaman primitif dari kebiasaan atau adat istiadat sampai dengan ketentuan yang diyakini bersama untuk dipatuhi sebagai hukum yang hidup di tengah-tengah masyarakat (the living law). Kedua, dari segi agama terdapat nilai-nilai agama yang diyakini bersama dijadikan sebagai sistem kehidupan yang dianggap sebagai hukum yang bersumber pada agama yang diyakini sebagian besar masyarakat. Ketiga, produk hukum penjajah Belanda yang juga diberlakukan pula di negara jajahannya bahkan memaksakan hukumnya kepada masyarakat jajahannya.

Kerumitan yang sama juga ditemui dalam intern umat Islam karena pemaknaan terhadap syariah itu sendiri memiliki problema tersendiri pula. Dimana mazhab pemikiran dan sistem hukum Islam tidak tunggal. Varian dan corak pemikiran dalam menyikapi hubungan syariah dan negara melahirkan tiga persimpangan jalan. Pertama, satu jalan menuju pemberlakuan hukum Islam berasal dari kelompok yang menghendaki hukum Islam dapat berlaku di Indonesia untuk mengatur pemeluknya. Kedua, satu jalan dari kelompok yang menginginkan adanya 
kesatuan dan keseragaaman hukum. Agama hanya sebagai bahan baku dalam pembentukan hukum nasional. Paradigma berpikir kelompok ini adalah menjaga hubungan antara syariat dan negara. Pada kondisi tertentu dilakukan formalisasi hukum Islam dalam perundang-undangan negara, pada saat yang lain Islam sebagai sumber etika moral. Perspektif ini disebut moderat-konstitusional. Ketiga, simpang jalan lainnya adalah kelompok yang tidak menginginkan berlakunya hukum Islam secara terlembaga dan bahkan ada kecenderungan menyingkirkan hukum Islam. Kubu pendukung paham ini diwakili sebagian besar non muslim dan sebagian kecil umat islam beraliran nasionalis sekuler. Perspektif ini disebut liberal-sekularistik.

Adapun perkembangan hukum Islam pada masa Orde Baru dilihat dari produk hukum yang dijadikan sebagai studi kasus dalam kajian ini misalnya Undang-Undang No. 1 tahun 1974 tentang Perkawinan yang lahir pada saat konfigurasi politik Indonesia sedang dalam konfigurasi politik oteriter, tapi karakter produk hukum Islam yang dihasilkannya bersifat responsif. Dari segi isi UU ini disebut responsif karena seluruh pasal- pasal yang termaktub dalam UU No. 1 tahun 19974 tentang Perkawinan telah sejalan dengan hukum Islam atau sekurang-kurangnya tidak bertentangan dengan hukum Islam. Begitu juga produk hukum UU No. 7 tahun 1989 tentang Peradilan Agama, dari perspektif pembentukan hukum berkarakter responsif karena akomodatif terhadap lembaga Pengadilan Agama yang menjadi bagian penting dalam kelembagaan hukum Islam di Indonesia, walaupun Undang-Undang No. 7 Tahun 1989 ini lahir saat konfigurasi politik otoriter. Sayangnya, dari segi implementasi materi hukumnya bersifat konservatif. Hal ini dilihat dari rendahnya perhatian elit politik untuk merealisasikan UUPA dan malah keberadaan lembaganya sudah ada jauh sebelum hukum formilnya dan malah kelahirannya terlambat dibandingkan dengan undang-undang peradilan lainnya. Selanjutnya, hal yang sama juga terjadi pada Kompilasi Hukum Islam, konfigurasi pemerintahan Orde Baru masih dinilai tidak demokratis. Namun dari segi isi sepenuhnya berisi ketentuan-ketentuan yang diangkat dari kitab-kitab fiqh rujukan umat islam yang memuat aspek-aspek hukum perkawinan, kewarisan dan perwakafan.

\section{DAFTAR PUSTAKA}

Ali, Daud. 1997. Hukum Islam dan Peradilan Agama, Jakarta: CPT. RajaGrafindo Persada 
Jurna: Faktor-faktor yang Mempengaruhi Penyerapan Hukum Islam... | 179 Ali, Fachry, 1986. Refleksi Paham Kekuasaan Jawa dalam Indonesia Modern. Jakarta: PT. Gramedia

Anshori, Abdul Ghofur. 2008. Hukum Islam Dinamika dan Perkembangannya di Indonesia. Jogyakarta: Kreasi Total Media

Azizi, A. Qodry. 2004. Hukum Nasional Elektisisme Hukum Islam \& Hukum Umum. Jakarta: Teraju

Bisri, Cik. 1997. Peradilan Islam dalam Tatanan Masyarakat Indonesia. Bandung: PT. Rosdakarya

Djalil, Basiq. 2006. Peradilan Agama di Indonesia. Jakarta: Kencana Prenada Group

Effendy, Bahtiar dan Fahry Ali. 1986.Merambah Jalan Baru Islam Rekonstruksi Pemikiran Islam Masa Orde Baru. Bandung: Mizan

Ghafar, Affan. 1993. Islam dan Politik Dalam Era Orde Baru: Mencari Bentuk Artikulasi yang Tepat. Jakarta: Ulmul Qur'an

Hasan, Kamal. 1987. Modernisasi Indonesia; Respons Cendekiawan Muslim. Jakarta: Lingkaran Studi Indonesia

Ichtijanto S.A. 1996. Prospek Peradilan Agama sebagai Peradilan Negeri dalam Sistem Politik Hukum Indonesia, dalam Amrullah Ahmad, editor. Dimensi Hukum Islam dalam Sistem Hukum Nasional. Jakarta: Gema Insani Press

Jackson, Karl D. 1978. Bureaucratic Polity: A Tjeoretical Framework for The Analysis of Power and Communication in Indonesia. Barkeley: California University Press

Joeniarto. 1990. Sejarah Ketatanegaraan Republik Indonesia. Jakarta: Bumi Aksara

Ka'bah, Rifyal. 1999. Hukum Islam di Indonesia. Jakarta: Universitas Yarsi

M. Zein, Satria Effendi. 1997. Ijtihad Sepanjang Sejarah Hukum Islam: Memposisikan KHLM. Ali Yafie, dalam Jamal D. Rahman (ed), Wacana Baru Fiqh Sosial 70 Tahun KHLM. Ali Yafie. Bandung: Mizan

Hukum Islam di Indonesia, dalam Muhammad Wahyu Nafis, (ed). Kontektualisasi Ajaran Islam 70 Tahun Prof. Dr. H. Munawir Sjadzali. MA. Jakarta: Paramadina

Mahfud MD. 2010. Politik Hukum di Indonesia. Jakarta: PT. RajaGrafindo Persada

Manan, Abdul. 2006. Aneka Masalah Hukum Perdata Islam Indonesia. Jakarta: Kencana Prenada Media Group 
180| Fokus : Jurnal Kajian Keislaman dan Kemasyarakatan, Vol.2, No. 02, Des 2017

Mc. Vey, Ruth T. 1982. The Bamtenstaat in Indonesia dalam Benedict Anderson dan Audrey Kahin (eds). Interpreting Indonesian Politict-Thirteen Contribution to Debate. Ithaca: Cornell University Ithaca

Mudzhar, Muhammad Atho. 1993. Fatwa-Fatwa Majelis Ulama Indonesia: Sebuah Studi tentang Pemikiran Hukum Islam di Indonesia 1975-1988. Jakarta: INIS

Muttaqien (ed), Dadan. 1999. Peradilan Agama dan Kompilasi Hukum Islam dalam Tata Hukum Indonesia. Yogyakarta: UII Press

Noeh, Zaini Ahmad. "Perkembangan Hukum Keluarga Islam Setelah 50 Tahun Kemerdekaan (Catatan untuk Ulang Tahun Emas Departemen Agama)": Mimbar Hukum, No. 24 tahun VII JanuariFebruari 1996

Noer, Deliar. 1996. Gerakan Modern Islam di Indonesia 1990-1942. cet. VII. Jakarta: LP3ES

Nuruddin, Amir dan Tarigan, Azhari Akmal. 2006. Hukum Perdata Islam di Indonesia. Jakarta: Kencana Prenada Media Group

Rasjidi, HM. 1989. Soal Peradilan Agama. Jakarta: Dewan Dakwah Islamiyah Indonesia Pusat

Ricklefs, M.C. 2008. diterjemahkan dari A History of Modern Indonesia Since c. 1200. Jakarta: PT. Serambi Ilmu Semesta

Roeder. 1985. Anak Desa: Biografi Presiden Soeharto. Jakarta: Gunung Agung

Saebani, Beni Ahmad dan Falah Syamsul. 2011. Hukum Perdata Islam di Indonesia. Bandung: Pustaka Setia

Saleh, K. Wantjik. 1987. Hukum Perkawinan Indonesia. Jakarta: Balai Aksara

Sartori, Giovani. 1976. Parties and Party Sistem: A Framework for Analysis. Cambridge: Cambridge Universiy Press

Shomad, Abd. 2010. Hukum Islam: Penormaan Prinsip Syari'ah dalam Hukum Indonesia. Jakarta: Kencana Prenada Media Group

Sjadzali, Munawir. 1991. Islam dan Tata Negara: Ajaran, Sejarah dan Pemikiran. Jakarta: UI Press

Sosroatmojo, Arso dan A. Wasit Aulawi. 1975. Hukum Perkawinan. Jakarta: Bulan Bintang

Subekti. Law in Indonesia. Jakarta: Yayasan Proklamasi Center for Starategic and International Studies 1982

Suseno, Franz Magnis. Tt. Seputar Rencana Undang-Undang Peradilan Agama Prof. Dr. HM Rasjidi Menjawab Magnis Suseno. Jakarta: Dewan Dakwah Islamiyah Indonesia Pusat 
Jurna: Faktor-faktor yang Mempengaruhi Penyerapan Hukum Islam... | 181 Syarifuddin, Amir. Meretas 2002. Kebekuan Ijtihad: Isu-Isu Penting Hukum Islam Kontemporer di Indonesia. Jakarta: Ciputat Press

Thaba, Abdullah Aziz. 1996. Islam dan Negara dalam Politik Orde Baru. Jakarta: Gema Insani Perss

Usman, Rachmadi. 2003. Perkembangan Hukum Perdata dalam Dimensi Sejarah dan Politik Huk um di Indonesia. Jakarta: Grafiti

Yaswirman. 2013. Hukum Keluarga: Karakteristik dan Prospek Doktrin Islam dan Adat dalam Masyarakat Matrilineal Minangkabau. Jakarta: PT. RajaGrafindo Persada 